\title{
Pengaruh Kecanggihan Investor Dan Kualitas Auditor Ter- hadap Hubungan Antara Manajemen Laba Sebelum Initial Public Offerings( Ipo) Dengan Return Saham
}

\author{
Marfuah'
}

\section{Abstract}

The main purpose of this research is to examine the availability profit management in scheme of IPO. In addition to this, the influence of the profit management on share return and also the influence of the sophistication of investor and the quality of auditor in the moderation of the relation between profit management before IPO and share return.

Based on the selecteed samples, 38 companies which has undertake IPO during 1995-2008 and the examination of "one-sample test" is found the indication of profit management one year prior to IPO. Whereas in the period of IPO and one year post$I P O$, is not found such management in the companies that undertakes an IPO. Based on Regresiion-Moderation Analysis is found that the sophistication of investor significantly renders negative influence towards the the relation between manajement of profit prior to IPO and share return.

Key words : IPO, profit management, sophistication of investor, quality of auditor

\section{Pendahuluan}

Salah satu peristiwa penting bagi perusahaan adalah saat perusahaan tersebut untuk pertama kalinya menawarkan sahamnya kepada publik atau melakukan Initial Public Offering (IPO). Dalam melakukan penawaran saham perdana, pemilik lama perusahaan (issuer) menginginkan agar proceeds yang diperoleh dari penjualan saham tinggi. Untuk dapat mencapai hal tersebut, issuer berusaha agar harga penawaran saham tinggi.

Akan tetapi untuk menetapkan harga penawaran perdana tersebut tidaklah mudah. Hal ini disebabkan tidak adanya informasi yang relevan, karena sebelum pelaksanaan IPO, saham perusahaan belum pernah diperdagangkan sehingga baik calon investor maupun issuer dan underwriter sama-sama menghadapi kesulitan untuk menilai dan menentukan harga saham yang wajar. Disamping itu, keterbatasan informasi membuat calon investor harus melakukan analisis menyeluruh sebelum memutuskan untuk membeli saham.

Sumber informasi yang pasti tersedia untuk melakukan analisis mengenai perusahaan yang akan go publik adalah prospektus. Informasi dalam prospektus yang menjadi perhatian utama adalah laporan keuangan, khususnya adalah informasi tentang laba. Menyadari ketergantungan calon investor dan underwriter terhadap informasi dalam prospektus membuat. issuer terdorong untuk menyajikan infromasi yang dapat memperlihatkan bahwa perusahaan mempunyai kinerja yang baik. Oleh karena itu, issuer berusaha mengatur tingkat laba yang dilaporkan dengan memilih metode-metode akuntansi tertentu sehingga dapat meningkatkan proceed dari hasil IP.O. Tindakan seperti ini dikenal dengan istilah manajemen laba (earnings management).

Beberapa penelitian yang bertujuan untuk menguji manajemen laba pada perusahaan yang melakukan IPO menemukan bukti bahwa perusahaan melakukan manajemen laba sebelum dan sesudah IPO. Friedlan (1994) menemukan bukti bahwa perusahaan-perusahaan

' Dosen Tetap Jurusan Akuntansi FE UII 
di Amerika Serikat menaikkan laba akuntansi perioda satu tahun sebelum IPO. Jain dan Kini (1994) menyatakan bahwa terdapat penurunan kinerja operasional perusahaan setelah IPO. Penurunan tersebut menunjukkan indikasi telah terjadi manajemen laba menjelang IPO. Teoh et al. (1998a) menemukan bahwa ada perusahaan yang berperilaku agresif (menaikkan laba) dan ada yang berperilaku konservatif ketika menyusun laporan keuangan satu perioda sebelum IPO.

Imam Sutanto (2000), Gumanti (2001), Syaiful (2002), Raharjono (2005) dan Joni dan Jogiyanto (2009) menemukan bahwa terjadi manajemen laba menjelang IPO di Bursa Efek Jakarta (BEJ). Gumanti (2001) dan Syaiful (2002) menyimpulkan bahwa manajemen melakukan manajemen laba perioda dua tahun menjelang IPO dan tidak terdapat indikasi manajemen laba perioda satu tahun menjelang IPO. Sedangkan Raharjono (2005) menemukan bahwa manajemen laba terjadi pada perioda satu tahun menjelang IPO. Sementara Joni dan Jogiyanto (2009) menemukan bahwa manajemen laba terjadi periode dua tahun dan satu tahun sebelum IPO.

Walaupun asimetri informasi antara manajemen dan investor tidak lagi tinggi setelah IPO, namun berbagai penelitian menunjukkan bahwa manajemen laba juga dilakukan setelah IPO. Friedlan (1994) menemukan bukti bahwa perusahaan-perusahaan di Amerika Serikat menaikkan laba akuntansi perioda satu tahun setelah IPO. Syaiful (2002) juga menemukan adanya manajemen laba perioda dua tahun setelah IPO.

Beberapa penelitian mengenai reaksi investor terhadap manajemen laba telah dilakukan. Teoh et al. (1998a). menemukan bahwa setelah IPO, return saham jangka panjang mengalami penurunan dibandingkan dengan perusahaan yang tidak melakukan IPO. Penurunan ini berhubungan dengan akrual diskresioner (discretionary accruals) di sekitar IPO. Manajemen laba berhubungan negatif terhadap return saham, artinya investor memberikan reaksi negatif terhadap praktik manajemen laba.

Syaiful (2002) juga melakukan studi di BEJ dan menemukan bahwa return saham satu tahun setelah IPO adalah rendah, namun penelitian ini tidak berhasil menemukan hubungan antara rendahnya return saham setahun setelah IPO dengan manajemen laba di sekitar IPO. Ardiati (2005) menemukan bahwa manajemen laba berpengaruh positif terhadap return dengan menggunakan kualitas audit sebagai variabel pemoderasi. Widiastuty (2004) juga menemukan bahwa manajemen laba berhubungan positif terhadap return saham dengan menggunakan leverage dan unexpected earnings sebagai variabel kontrol. Sedangkan Raharjono (2005) menemukan bukti bahwa tidak terdapat hubungan antara manajemen laba perioda satu tahun sebelum IPO dengan return saham setelah IPO. Jadi hasil penelitian mengenai hubungan manajemen laba dengan return di BEI masih beragam dan belum konsisten dengan teori yang ada.

Ketidak konsistenan hasil tersebut diduga karena adanya faktor yang mempengaruhi hubungan antara manajemen laba dengan return saham. Bartov et al. (2000a) menyatakan bahwa kecanggihan investor (investor sophistication) merupakan faktor penentu hubungan antara laba dan return. Menurut Balsam et al. (2002), para investor yang canggih (sophisticated investors) mampu mendeteksi manajemen laba lebih cepat daripada para investor yang tidak canggih (unsophisticated investors). Joni dan Jogiyanto (2009) menyatakan bahwa manajemen laba yang tinggi menyebabkan nilai harga saham rendah ketika mempertimbangkan faktor kecanggihan investor. Hasil ini konsisten dengan temuan Balsam et al. (2002) yang menyatakan bahwa manajemen laba berhubungan dengan return saham untuk investor yang canggih.

Dessy dan Indra (2004) menyatakan bahwa, kualitas auditor dan kepemilikan manajerial diduga merupakan faktor penentu hubungan manajemen laba dengan return saham. Menurut 
Dessy dan Indra (2004), untuk mengurangi perilaku manipulasi laba oleh manajemen, diperlukan mekanisme pengawasan atau kontrak. Salah satunya adalah audit atas laporan keuangan. Manajemen perusahaan sebagai agen memerlukan jasa pihak ketiga agar tingkat kepercayaan pihak eksternal terhadap informasi yang disajikan oleh perusahaan semakin tinggi, demikian sebaliknya pihak eksternal perusahaan memerlukan jasa pihak ketiga untuk meyakinkan dirinya bahwa informasi keuangan yang disajikan oleh manajemen perusahaan dapat dipercaya sebagai dasar pengambilan keputusan. Dengan demikian kualitas auditor akan menambah keyakinan investor bahwa perilaku manajer untuk melakukan tindakan memanipulasi laba dapat diminimalisasi.

Penelitian ini merupakan pengembangan penelitian Joni dan Jogiyanto (2009) dengan menambahkan satu variabel pemoderasi dalam persamaan regresi yaitu variabel kualitas auditor. Oleh karena penelitian ini mempunyai dua tujuan yang ingin dicapai, yaitu: (1) Untuk mendeteksi adanya manajemen laba periode di sekitar IPO pada perusahaan yang terdaftar di Bursa Efek Indonesia dan (2) Untuk menguji apakah kecanggihan investor dan kualitas auditor merupakan faktor yang mempengaruhi hubungan antara manajemen laba dengan return saham.

\section{Kajian Teoretis Dan Pengembangan Hipoteșiș}

Pada bagian ini akan diuraikan teori yang berhubungan dengan manajemen laba dan beberapa penelitian terdahulu yang mendukung perumusan hipotesis.

\section{IPO dan Manajemen Laba}

Asimetri informasi antara pihak manajemen dan investor potensial sangat tinggi ketika perusahaan belum melakukan IPO. Hal ini disebabkan karena informasi perusahaan yang belum go public relatif sulit diperoleh investor. Ketika perusahaan melakukan IPO, investor potensial hanya mengandalkan informasi dari prospektus. Menurut Rao (1993) dalam Teoh et al. (1998a) tidak terdapat media lain yang menyediakan informasi perusahaan yang sedang melakukan IPO, kecuali prospektus yang disyaratkan Pengawas Pasar Modal. Kelangkaan informasi perusahaan sebelum IPO, memaksa investor potensial hanya mengandalkan. prospektus sebagai sumber informasi mengenai perusahaan. Padahal prospektus hanya menyediakan laporan keuangan selama tiga tahun sebelum IPO dan informasi non keuangan (Teoh et al. 1998a). Kondisi inj memberikan kesempatan bagi manajemen untuk melakukan manajemen laba supaya meningkatkan kemakmurannya, yaitu mengharapkan harga saham akan tinggi pada saat IPO.

Beberapa penelitian yang bertujuan untuk menguji manajemen laba pada perusahaan yang melakukan IPO menemukan bukti bahwa perusahaan melakukan manajemen laba sebelum dan sesudah IPO. Friedlan (1994) menemukan bukti bahwa perusahaan-perusahaan di Amerika Serikat menaikkan laba akuntansi perioda satu tahun sebelum IPO. Jain dan Kini (1994) menyatakan bahwa terdapat penurunan kinerja operasional perusahaan setelah IPO. Penurunan tersebut menunjukkan indikasi telah terjadi manajemen laba menjelang IPO. Teoh et al. (1998a) menemukan bahwa ada perusahaan yang berperilaku agresif (menaikkan laba) dan ada yang berperilaku konservatif ketika menyusun laporan keuangan satu perioda sebelum IPO.

Imam Sutanto (2000), Gumanti (2001), Syaiful (2002), Raharjono (2005) dan Joni dan Jogiyanto (2009) menemukan bahwa terjadi manajemen laba menjelang IPO di Bursa Efek Jakarta (BEJ). Gumanti (2001) dan Syaiful (2002) menyimpulkan bahwa manajemen melakukan manajemen laba perioda dua tahun menjelang IPO dan tidak terdapat indikasi manajemen laba perioda satu tahun menjelang IPO. Sedangkan Raharjono (2005) menemukan 
bahwa manajemen laba terjadi pada perioda satu tahun menjelang IPO. Sementara Joni dan Jogiyanto (2009) menemukan bahwa manajemen laba terjadi periode dua tahun dan satu tahun sebelum IPO.

Walaupun asimetri informasi antara manajemen dan investor tidak lagi tinggi setelah IPO, namun berbagai penelitian menunjukkan bahwa manajemen laba juga dilakukan setelah IPO. Friedlan (1994) menemukan bukti bahwa perusahaan-perusahaan di Amerika Serikat menaikkan laba akuntansi perioda satu tahun setelah IPO. Syaiful (2002) juga menemukan adanya manajemen laba perioda dua tahun setelah IPO.

Berdasarkan landasan teori dan hasil penelitian sebelumnya, maka dapat dirumuskan hipotesis alternatif berikut:

H1a: Perusahaan yang terdaftar di BEl melakukan manajemen laba sebelum IPO.

H1b: Perusahaan yang terdaftar di BEI melakukan manajemen laba pada saat IPO.

H1c: Perusahaan yang terdaftar di BEl melakukan manajemen laba setelah IPO.

\section{Manajemen Laba dan Return Saham}

Return saham perusahaan setelah IPO dalam jangka panjang akan turun. Hal ini disebabkan investor terlalu optimis, sehingga harga saham akan lebih tinggi pada awal penawarannya dan berangsur-angsur turun dalam jangka panjang (Brav dan Gompers 1997). Kemudian Brav et al. (2000) melakukan pengujian terhadap abnormal return yang mengikuti penawaran sekuritas. Mereka menyimpulkan bahwa kinerja saham rendah untuk perusahaan yang memiliki book to market ratio rendah. Teoh et al. (1998a) meneliti kinerja perusahaan jangka panjang setelah IPO, hasilnya menggambarkan return saham jangka panjang rendah setelah IPO dibandingkan dengan perusahaan yang tidak melakukan IPO. Mereka juga membuktikan bahwa kinerja yang rendah tersebut berhubungan dengan akrual diskresioner di sekitar IPO.

Syaiful (2002) meneliti hubungan manajemen laba dengan return saham perusahaan yang terdaftar di BEJ. Penelitian dilakukan terhadap 44 perusahaan yang melakukan IPO pada 1991-1994. Hasilnya menunjukkan bahwa return saham pada perioda satu tahun setelah IPO rendah. Tetapi penelitian ini tidak berhasil menemukan hubungan antara manajemen laba dan return saham. Raharjono (2005) juga meneliti mengenai hubungan antara manajemen laba dengan return saham perusahaan yang terdaftar di BEJ. Penelitian dilakukan pada 33 perusahaan yang melakukan IPO pada 1995-2001. Hasilnya menunjukkan tidak terdapat hubungan antara manajemen laba perioda satu tahun sebelum IPO dan return saham satu tahun setelah IPO.

\section{Kecanggihan Investor, Manajemen Laba dan Return Saham}

Ketidak konsistenan hasil tersebut diduga karena adanya faktor yang mempengaruhi hubungan antara manajemen laba dengan return saham.Bartov et al. (2000a) menyatakan bahwa kecanggihan investor (investor sophistication) merupakan faktor penentu hubungan antara laba dan return. Menurut Balsam et al. (2002), para investor yang canggih (sophisticated investors) mampu mendeteksi manajemen laba lebih cepat daripada para investor yang tidak canggih (unsophisticated investors). Joni dan Jogiyanto (2009) menyatakan bahwa manajemen laba yang tinggi menyebabkan nilai harga saham rendah ketika mempertimbangkan faktor kecanggihan investor. Hasil ini konsisten dengan temuan Balsam et al. (2002) yang menyatakan bahwa manajemen laba berhubungan dengan return saham untuk investor yang canggih. 
Rajgopal et al. (1999) menguji hubungan manajemen laba dengan kecerdasan investor menggunakan data perioda .1989-1995. Hasilnya menunjukkan bahwa manajemen laba berhubungan negatif dengan kecerdasan investor. Hasil ini menyatakan bahwa semakin tinggi tingkat kecerdasan investor, maka semakin rendah tingkat manajemen laba dan sebaliknya.

Berdasarkan uraian di atas, maka dirumuskan hipotesis penelitian berikut:

$\mathrm{H} 2$ : Kecanggihan investor mempengaruhi hubungan antara Manajemen laba sebelum IPO dengan return saham.

\section{Kualitas Auditor, Manajemen Laba dan Return Saham}

Dessy dan Indra (2004) menyatakan bahwa, kualitas auditor dan kepemilikan manajerial diduga merupakan faktor penentu hubungan manajemen laba dengan return saham. Menurut Dessy dan Indra (2004), untuk mengurangi perilaku manipulasi laba oleh manajemen, diperlukan mekanisme pengawasan atau kontrak. Salah satunya adalah audit. atas laporan keuangan. Manajemen perusahaan sebagai agen memerlukan jasa pihak ketiga agar tingkat kepercayaan pihak eksternal terhadap informasi yang disajikan oleh perusahaan semakin tinggi, demikian sebaliknya pihak eksternal perusahaan memerlukan jasa pihak ketiga untuk meyakinkan dirinya bahwa informasi keuangan yang disajikan oleh manajemen perusahaan dapat dipercaya sebagai dasar pengambilan képutusan. Semakin tinggi kualitas auditor, maka investor akan semakin percaya terhadap informasi yang disajikan oleh perusahaan karena kemungkinan manajemen melakukan manipulasi laba akan semakin kecil.

Ardiati (2005) meneliti hubungan manajemen laba terhadap return saham dengan menggunakan kualitas audit sebagai variabel pemoderasi. Sampel penelitian terdiri atas 78 perusahaan pada perioda 1995-2000. Hasilnya menunjukkan bahwa manajemen laba berpengaruh positif terhadap return saham pada perusahaan yang diaudit KAP Big 5 dan berpengaruh negatif pada perusahaan yang diaudit KAP Non-Big 5.

Berdasarkan uraian di atas, maka dirumuskan hipotesis penelitian berikut:

H3:Kualitas auditor mempengaruhi hubungan antara Manajemen laba sebelum IPO dengan return saham.

\section{Metode Penelitian}

Pada bagian ini diuraikan metode pengambilan sampel, data dan metode pengumpulan data, definisi dan pengukuran variabel serta metode analisis data.

Metode Pengambilan Sampel

Sampel penelitian diambil dari perusahaan yang terdaftar di Bursa Efek Indonesia dan melakukan IPO mulai 1995 sampai 2008. Teknik pengambilan sampel menggunakan metode purposive, dengan ketentuan sebagai berikut:

1. Perusahaan tidak dikelompokkan kedalam jenis industri jasa keuangan. Hal ini disebabkan karena jenis industri keuangan sangat rentan terhadap regulasi dan memiliki perbedaan karakteristik akrual dibandingkan jenis industri lainnya.

2. Perusahaan tidak tergolong kedalam jenis industri perhotelan, travel, transportasi, dan real estate. Hal ini ditetapkan karena jenis industri tersebut memiliki karakteristik keuangan yang berbeda dengan jenis industri perdagangan dan industri pemanufakturan.

3. Perusahaan menerbitkan laporan keuangan selama empat tahun pengamatan, yaitu dua tahun sebelum IPO, saat IPO dan satu tahun setelah IPO.

4. Tersedia semua data yang dibutuhkan. 
Berdasarkan kriteria di atas, terdapat 51 perusahaan manufaktur yang melakukan go public dari tahun $1995 \mathrm{~s} / \mathrm{d} 2008$. Dari 51 perusahaan tersebut, terdapat 13 perusahaan yang datanya tidak lengkap, sehingga yang memenuhi kriteria sebanyak 38 perusahaan yang akan dijadikan sampel penelitian. Gambaran mengenai karakteristik sampel yang digunakan dapat dilihat di tabel 3.1 berikut ini:

Tabel 01. Proses Pemilihan sampel

\begin{tabular}{|l|c|}
\hline \multicolumn{1}{|c|}{ Keterangan } & Jumlah Perusahaan \\
\hline Perusahaan manufaktur go publik tahun 1995 s/d 2008 & 51 \\
\hline Data tidak lengkap & $(13)$ \\
\hline Sampel akhir & 38 \\
\hline
\end{tabular}

Data dan Metode Pengumpulan Data

Data yang akan digunakan pada penelitian ini menggunakan data sekunder. Yaitu laporan keuangan tahunan perusahaan manufaktur yang terdaftar di Bursa Efek Indonesia. Periode data yang digunakan selama tahun 1996 - 2008. Data tersebut diperoleh dari Indonesian Capital Market Directory (ICMD), situs Bursa Efek Indonesia www.idx.co.id dan pojok BEI Fakultas Ekonomi Universitas Islam Indonesia.

Definisi dan Pengukuran Variabel

Variabel dalam penelitian ini terdiri dari tiga jenis variabel, yaitu variabel dependen, variabel independen dan variabel pemoderasi. Variabel return saham atau CAR sebagai variabel dependen, manajemen labasebagai variabel independen, sedangkan variabel kecanggihan investor dan kualitas auditor sebagai variabel pemoderasi.

1. Return saham

Variabel dependen dalam penelitian ini adalah return saham yang diukur dengan menggunakan Cumulative Abnormal Return (CAR)selama tujuh hari setelah perusahaan terdaftar di BEl. CARdihitung dengan pendekatan Marketadjusted Model (model pasar disesuaikan). Formula CAR adalah sebagai berikut:

$$
\mathrm{CAR}_{\mathrm{it}}=\Sigma\left(\left(1+R_{\mathrm{tt}} / 1+R_{\mathrm{mt}}\right)-1\right)
$$

Keterangan:

$$
\begin{aligned}
& \mathbf{R}_{\mathrm{tt}}=\frac{\mathrm{P}_{\mathrm{i}}-\mathrm{P}_{\mathrm{t}-1}}{\mathrm{P}_{\mathrm{t}-1}} \\
& \mathbf{R}_{\mathrm{mt}}=\frac{I H S G_{\mathrm{t}}-I H S G_{\mathrm{t}-1}}{I H S G_{\mathrm{t}-1}}
\end{aligned}
$$

$\mathbf{C A R}_{\mathrm{t}, \mathrm{t}}=$ Cumulative Abnormal Return saham ${ }_{\mathrm{t}}$ pada hari,

$\mathbf{R}_{\mathrm{lt}}$ : Return sesungguhnya saham i pada hari $t$

$\mathbf{P}_{1:}$ : Harga penutupan (closing price) saham, pada hari,

$\mathbf{P}_{\mathrm{it}-1}$ : Harga penutupan (closing price) saham, pada hari $\mathrm{t}_{\mathrm{t}-1}$

$\mathbf{R}_{\mathrm{mt}}$ : Return Pasar

IHSG: Indeks Harga Saham Gabungan pada hari,

IHSG $_{\mathrm{t}-1}$ : Indeks Harga Saham Gabungan pada hari $\mathrm{t}_{\mathrm{t}-1}$ 
2. Manajemen Laba

Manajemen laba merupakan suatu intervensi dengan maksud tertentu terhadap proses pelaporan keuangan eksternal dengan sengaja untuk memperoleh beberapa keuntungan pribadi (Schipper, 1989). Manajemen laba adalah intervensi atau campur tangan dalam proses penyusunan laporan keuangan dengan tujuan untuk memaksimalkan keuntungan pribadi. Dalam penelitian ini manajemen laba diproksi dengan menggunakan model Jones yang dimodifikasi, karena pada penelitian Dechow (1995) dalam Setiawati dan. Saputro (2004) membuktikan bahwa model ini lebih mampu mendeteksi tingkat manajemen laba dibandingkan model estimasi lain seperti model Jones (1991), model Healy (1985), model DeAngelo (1986) dan model industri. Proksi tersebut digunakan untuk mengetahui besarnya discretionary acrual (DA), karena manajemen laba terjadi apabila nilai DA $>0$. Adapun pengujian nilai DA dilakukan dengan pendekatan statistik parametrik, yaitu one sample t-test.

Discretionary Accrual dan Nilai total akrual diestimasi dengan menggunakan rumus sebagai berikut :

$\mathrm{TA}_{\mathrm{r}} / \mathrm{A}_{\mathrm{tt}-1}=\left(\mathrm{NI}_{\mathrm{t}}-\mathrm{CFO}_{\mathrm{t}}\right) / \mathrm{A}_{\mathrm{t}-1}$

Nilai total accrual (TA) yang diestimasi dengan persamaan regresi sebagai berikut:

$\mathrm{TA}_{\mathrm{it}} / \mathrm{A}_{\mathrm{it}-1}=\mathrm{a}_{1}\left(1 / \mathrm{A}_{\mathrm{it}-1}\right)+\mathrm{a}_{2}\left(\Delta R E V_{\mathrm{it}} / \mathrm{A}_{\mathrm{it}-1}-\Delta \mathrm{REC}_{\mathrm{it}} / \mathrm{A}_{\mathrm{it}-1}\right)+\mathrm{a}_{3}\left(\mathrm{PPE}_{\mathrm{it}} / \mathrm{A}_{\mathrm{it}-1}\right)+\varepsilon_{\mathrm{it}}$

Dengan menggunakan koefisien regresi diatas, nilaj non discretionary accruals (NDA) dapat dihitung dengan rumus:

$\mathrm{NDA}_{\mathrm{tt}}=\alpha_{1}\left(1 / \mathrm{A}_{\mathrm{tt}-1}\right)+a_{2}\left(\Delta \mathrm{REV}_{\mathrm{lt}} / \mathrm{A}_{\mathrm{tt}-1}-\Delta \mathrm{REC}_{\mathrm{lt}} / \mathrm{A}_{\mathrm{tt}-1}\right)+\alpha_{3}\left(\mathrm{PPE}_{\mathrm{tt}} / \mathrm{A}_{\mathrm{tt}-1}\right)$

Selanjutnya discretionary accruals (DA) dapat dihitung sebagai berikut:

$\mathrm{DA}_{\mathrm{it} .} \quad=\mathrm{TA}_{\mathrm{tt}} / \mathrm{A}_{\mathrm{it}-1}-\mathrm{NDA}_{\mathrm{it}}$

Keterangan :

TA $=$ Total akrual perusahaan pada perioda $\mathrm{t}$

$\mathrm{NI}_{\mathrm{t}} \quad$ = Net Income / Laba bersih perusahaan pada perioda $\mathrm{t}$.

$\mathrm{CFO}_{\mathrm{t}}=$ Arus kas dari kegiatan operasi perusahaan pada perioda $\mathrm{t}$

$A_{i t-1} . \quad=$ total aktiva perusahaan i perioda $t-1$

$\mathrm{DA}_{\mathrm{it}} \quad=$ Discretionary accrua/perusahaan $\mathrm{i}$ pada perioda ke $\mathrm{t}$.

$\mathrm{NDA}_{\mathrm{it}}=$ non discretionary accruals perusahaan i pada perioda ke $\mathrm{t}$.

$\triangle R E V_{\mathrm{it}}=$ Perubahan pendapatan dari perioda $\mathrm{t}-1$ ke perioda $\mathrm{t}(\mathrm{REVt}-\mathrm{REVt}-1)$

$\triangle R E C^{\prime}=$ Perubahan nilai bersih piutang dari perioda $t-1$ ke perioda $t\left(R E C_{t}-R E C_{t-1}\right)$

$\mathrm{PPE}_{\mathrm{it}} \quad=$ gross property, plant, and equipment pada perioda $\mathrm{t}$

$\alpha_{1}, a_{2}, a_{3}=$ firm- specific parameters

$\varepsilon_{\mathrm{it}}=$ error term perusahaan $\mathrm{i}$ pada perioda $\mathrm{t}$

3. Kecanggihan Investor

Investor yang canggih adalah investor yang mampu mengumpulkan, memproses informasi publik dan mengambil keputusan yang sahih, sedangkan investor yang tidak cerdas adalah investor yang hanya menggunakan informasi keuangan pers dan intuisi 
UNISIA, Vol. XXXIV No. 77 Juli 2012

serta tidak melakukan analisis laporan keuangan dengan baik (Bartov et al., 2000a dan Jogiyanto, 2005). Penelitian ini menggunakan kepemilikan institusi sebagai proksi kecanggihan investor dan cutoff $40 \%$ atau lebih kepemilikan institusi menunjukkan investor canggih. Sedangkan kepemilikan institusi di bawah $40 \%$ menunjukkan investor tidak canggih (Balsam et al. 2002).

4. Kualitas Auditor

Variabel kualitas auditor diukur dengan dummy, angka satu untuk auditor yang diasumsikan berkualitas tinggi dan angka nol untuk auditor yang diasumsikan berkualitas rendah. Dalam. penelitian ini, auditor yang diasumsikan mempunyai kualitas tinggi adalah auditor yang tergolong the Big Five, sebaliknya auditor yang mempunyai kualitas rendah adalah auditor yang tidak tergolong the Big Five.Adapun kelompok auditor Big Five adalah sebagai berikut:

1. KAP Arthur Andersen (di Indonesia berafiliasi dengan KAP Prasetio Utomo \& Co)

2. KAP Deloitte Touche Tohmatsu (di Indonesia berafiliasi dengan KAP Hans Tuanakotta Mustofa)

3. KAP Ernst \& Young (di Indonesia berafiliasi dengan KAP Hanadi, Sarwoko, dan Sandjaja)

4. KAP Pricewaterhouse Coopers (di indonesia berafiliasi dengan Drs. Hadi Susanto \& rekan)

5. KAP Klynveld Peat Marwick Goerdeler/KPMG (di Indonesia berafiliasi dengan KAP Sidharta, Sidharta dan Harsono).

Metode Analisis Data

Indikasi bahwa telah terjadi manajemen laba dengan menaikkan tingkat laba (incomeincresing discretionary accruals) ditunjukkan oleh DAC yang bernilai positip. Sebaliknya bila nilai DAC bernilai negatip maka ada indikasi terjadi income-decresing discretionary accruals. Pengujian hipotesis $\mathrm{H} 1 . \mathrm{a}, \mathrm{H} 1 . \mathrm{b}$ dan $\mathrm{H} 1 . \mathrm{c}$ dilakukan dengan mengunakan one sample t-test. Adapun hipotesis 2 dan 3 diuji menggunakan analisis regresi dengan menggunakan persamaan berikut:

$$
\mathrm{CAR}_{i}=\beta_{0}+\beta_{1} \mathrm{DAC}_{i}+\beta_{2} \mathrm{INST}_{i}+\beta_{3} \mathrm{AUDIT}_{1}+\beta_{4} \mathrm{DAC}_{i}{ }^{*} \mathrm{INST}_{i}+\beta_{5} \mathrm{DA}_{1}^{\star} \mathrm{AUDIT}_{i}++e_{i} \ldots \ldots
$$

Keterangan:

CAR : cumulatif abnormal return perusahaan i

$\mathrm{DAC}_{i}$ : discretionary accruals perusahaan $\mathrm{i}$

INST $_{i}$ : kepemilikan institusi perusahaan i

AUDIT, : kualitas auditor perusahaan $\mathrm{i}$

Dari persamaan regresi tersebut, diprediksi bahwa koefisien regresi $\beta_{4}$ dan $\beta_{5}$ bertanda negatif.

\section{Analisis Data Dan Pembahasan}

Pada bagian ini diuraikan mengenal analisis data yang terdiri atas deskripsi data dari variabel-variabel penelitian, uji asumsi klasik dan uji hipotesis. 
Statistik Deskriptif

Tabel 02 berikut disajikan deskripsi data dari masing-masing variabel penelitian yang terdiri dari nilai minimum, nilai maksimum, rata-rata dan standar deviasi.

Tabel 02. Deskriptive Variabel Penelitian

\begin{tabular}{|l|c|c|c|c|c|}
\hline Variabe] & $\mathbf{N}$ & Minimum & Maximum & Mean & $\begin{array}{c}\text { Std. } \\
\text { Deviation }\end{array}$ \\
\hline CAR & 38 & -.648320 & .429270 & -.046961 & .242693059 \\
\hline$D A$ & 38 &. .306250 & .856209 & .10215892 & .225685134 \\
\hline INST & 38 & .000000 & 1.000000 & .18421053 & .392859452 \\
\hline AUDT & 38 & .000000 & 1.000000 & .65789474 & .480782908 \\
\hline
\end{tabular}

Tabel 02 menunjukkan bahwa perusahaan memiliki rata-rata nilai cumulative abnormal return (akumulasi return abnormal selama tujuh hari setelah perusahaan terdaftar di BEI) sebesar - .046961 dengan nilai deviasi standar sebesar .242693059. Nilai cumulative abnormal returnyang bernilai negatif ini mengindikasikan bahwa rata-rata saham yang melakukan IPO selama 7 hari paska penawaran saham perdana ini mengalami kecenderungan penurunan harga.

Nilai akrual diskresioner (DA) yang merupakan ukuran manajemen laba memiliki nilai rata-rata sebesar 0.10215892 dan standar deviasi sebesar 0.225685134 . Nilai DA yang positif menunjukkan bahwa rata-rata perusahaan yang melakukan IPO, cenderung melakukan manajemen laba dengan increasing income yaitu manajemen laba dengan motivasi menaikkan laba.

Variabel Kepemilikan institusi menunjukkan bahwa rata-rata kepemilikan institusional adalah 0.18421053 atau jauh dibawah $40 \%$. Hal ini menunjukkan bahwa sebagian besar perusahaan yang melakukan IPO.di Bursa Efek Indonesia mayoritas melibatkan investor yang tidak cerdas, sehingga ada kecenderungan perusahaan untuk melakukan manajemen laba.

Rata-rata variabel kualitas auditor adalah .65789474. Ini menunjukkan bahwa sebagian besar yaitu $65 \%$ perusahaan menggunakan auditor yang berkualitas (big five).

Uji Asumsi Klasik

Uji asumsi klasik yang dilakukan dalam penelitian ini meliputi uji Normalitas, uji Multikolinieritas, uji Heteroskedastisitas, dan uji Autokorelasi.

Uji Normalitas

Uji normalitas bertujuan untukmenguji apakah dalam model regresi, variabel pengganggu atau residual memiliki distribusi normal. Uji normalitas dilakukan dengan normal probably plot of standardized residual. Berdasarkan gambar normal probably plot of standardized residual - dapat dilihat bahwa titik-titik menyebar di sekitar garis diagonal dan penyebarannya mengikuti arah garis diagonal. Dengan demikian dapat disimpulkan bahwa penyebaran data mendekati normal atau memenuhi asumsi normalitas.

Uji Multikolinearitas

Berdasarkan hasil analisis regesi diketahui bahwa semua nilai tolerance lebih dari $0,1(>0,1)$, sedangkan semua nilai VIF kurang dari $10(<10)$. Oleh karena itu semua variabel independen yang digunakan pada penelitian ini tidak mengandung muitikolinearitas.

Uji Heteroskedastisitas

Uji heteroskedastisitas bertujuan menguji apakah dalam model regresi terjadi ketidaksamaan varian dari residual satu pengamatan ke pengamatan yang lain. Uji 
Heteroskedastisitas dalam penelitian ini diukur dengan metode plot. Berdasarkan gambar scatterplot menunjukkan adanya titik-titik yang menyebar di atas dan di bawah sumbu $Y$, serta tidak membentuk pola, sehingga model regresi tidak terjadi heteroskedastisitas.

\section{Uji Autokorelasi}

Uji autokorelasi bertujuan menguji apakah dalam model regresi linier ada korelasi antara kesalahan pengganggu pada periode $t$ dengan kesalahan pengganggu pada periode $t-1$. Pengujian autokorelasi menggunakan Durbin Watson. Berdasarkan analisis regresi diketahui nilai Durbin Watson sebesar 1,066 yang berada di antara -2 sampai +2 . Artinya model regresi tidak ada autokorelasi.

Pengujian Hipotesis

Pengujian hipotesis H1.a, H1.b dan H1.c dilakukan dengan mengunakan one sample t-test. Adapun hipotesis 2 dan 3 diuji menggunakan analisis regresi linear moderasi (MRA).

\section{Hasil Pengujian Hipotesis Pertama}

Hipotesis pertama terdiri dari 3 hipotesis, yaitu: H1a: Perusahaan yang terdaftar di $\mathrm{BE}$ melakukan manajemen laba sebelum IPO, $\mathrm{H} 1 \mathrm{~b}$ : Perusahaan yang terdaftar di BEl melakukan manajemen laba pada saat IPO dan H1c: Perusahaan yang terdaftar di BEI melakukan manajemen laba setelah IPO. Dengan pendekatan tersebut manajemen laba terjadi jika discretionary accrual $(D A)>0$. Untuk menguji apakah nilai $D A>0$ atau tidak, digunakan uji bedaone sampel $t$ test. Hasil pengujian one sample t-test disajikan pada tabel 4.2 berikut:

Tabel 03. Uji One Sampel t-test Manajemen Laba Di Sekitar IPO

\begin{tabular}{|l|l|l|l|l|}
\hline Keterangan & \multicolumn{1}{|c|}{ t-statistik } & \multicolumn{1}{|c|}{ Sig. (2 tailed) } & \multicolumn{1}{|c|}{ Mean Difference } & \multicolumn{1}{c|}{ Kesimpulan } \\
\hline DAC. T-1 & 2.790 & 0.008 & 0.10215842 & H1a didukung \\
\hline DAC.T & -2.669 & 0.011 & -0.09511361 & H1b didukung \\
\hline DAC.T+1 & 0.132 & 0.896 & 0.01980524 & H1c tidak didukung \\
\hline
\end{tabular}

Berdasarkan tabel 03 di atas diketahui bahwa nilai mean DAC pada periode 1 tahun sebelum IPO adalah sebesar 0,10215842 dengan probabilitas sebesar 0.008 . Hal ini mengindikasikan bahwa pada periode 1 tahun sebelum IPO, perusahaan cenderung melakukan manajemen laba dengan cara meningkatkan laba (increasing income).

Pada periode terjadinya IPO, nilaj rata-rata DAC sebesar $-0,09511361$ dengan probabilitas sebesar 0.011 . Hal inimengindikasikan bahwa pada saat IPO terjadi manajemen laba dengan cara menurunkan laba (decreasing income),karena nilai DAC kurang nol. Sementara pada periode 1 tahun sesudah IPO, nilai rata-rata DAC sebesar 0.1980524 dengan probabilitas sebesar 0.896 , yang berarti tidak terjadi manajemen laba pada periode 1 tahun sesudah IPO.

Hasil penelitian ini mengindikasikan bahwa manajemen cenderung melakukan manajemen laba pada periode 1 tahun sebelum IPO dan pada periode terjadinya IPO. Oleh karena ituH la yang menyatakan bahwaPerusahaan yang terdaftar di BEI melakukan manajemen laba sebelum IPO dan $\mathrm{H} 1 \mathrm{~b}$ yang menyatakan bahwa perusahaan yang terdaftar di BEl melakukan manajemen laba pada saat IP, didukung.

Hasil penelitian ini sesuai dengan hasil penelitian Sutanto (2000), Gumantio (2001) Syaiful (2002) dan Raharjono (2005) yang membuktikan adanya manajemen laba menjelang IPO di Bursa Efek Indonesia. Pada saat IPO prospektus merupakan satu-satunya sumber informasi dalam proses penawaran saham perdana ini, sebab selain prospektus hampir tidak ada sumber informasi lain yang tersedia untuk investor. Sebagai perusahaan tertutup yang 
mayoritas kepemilikannya dikuasai keluarga atau kelompok tertentu maka jarang ada media yang meliput nilai dan kondisi perusahaan itu sebelum perusahaan go public. Oleh sebab itu, investor cenderung menyandarkan diri kepada prospektus untuk mengetahui informasi dan menilai perusahaan yang melakukan penawaran saham itu.Investor menjadi tergantung pada informasi yang dicantumkan dalam prospektus. Kualitas informasi yang diterima dan dikuasai investor sangat tergantung pada kualitas informasi yang ada dalam prospektus perusahaan pada saat penawaran saham perdana. Minimnya informasi yang tersedia ini akan mendorong dan mẹmotivasi manajer perusahaan untuk melaporkan informasi yang menguntungkan dirinya dengan mempercantik laporan keuangan.

Hal ini akan memberikan dorongan bagi manajer untuk menerbitkan prospektus sebaik mungkin termasuk informasi keuangan yang ada didalamnya. Hal tersebut akan memberikan dorongan kepada manajer untuk memanfaatkan kesempatan dari ketidak seimbangan. kepemilikan informasi (asymmetric information) tentang perusahaan atau hal ini dikenal sebagai opportunistic behavior untuk mempengaruhi keputusan calon investor dengan mengatur tingkat laba perusahaan.

Semakin bagus informasi yang dipublikasikan perusahaan semakin bagus pula harga saham perusahaan bersangkutann atau sebaliknya semakin buruk informasi yang dipublikasikan perusahaan semakin buruk púla harga sahamnya.Inilah sebabnya mengapa kebanyakan manajer melakukan manajemen laba menjelang penawaran saham perdana. Perusahaan memiliki dorongan untuk melakukan manajemen laba yang dapat meningkatkan penerimaan melalui pengaturan tingkat laba yang dilaporkan dalam prospektus (increasing income).

\section{Hasil Pengujian Hipotesis Kedua dan Ketiga}

Untuk menganalisis hubungan manajemen laba dan return saham dengan kecanggihan investor dan kualitas auditor sebagai variabel moderasi, digunakan Analisis Regresi Moderasi. Analisis ini digunakan untuk menguji hipotesis kedua yang menyatakan bahwakecanggihan investor mempengaruhi hubungan negatif antara manajemen laba dengan return saham dan hipotesis ketiga yang menyatakan bahwakualitas auditor mempengaruhi hubungan negatif antara manajemen laba dengan return saham. Hasil analisis regresi moderasi dapat ditunjukkan. seperti pada Tabel 04 berikut:

Tabel 04. Hasil Regresi Moderasi

\begin{tabular}{|l|c|c|c|}
\hline \multicolumn{1}{|c|}{ Variabel } & B & t & sig \\
\hline (Constant) & -0.035 & -0.605 & 0.551 \\
\hline DAC & -0.143 & -0.607 & 0.550 \\
\hline INST & 0.177 & 2.127 & 0.041 \\
\hline AUDT & 0.058 & 0.681 & 0.652 \\
\hline$D A C^{\star} I N S T$ & -1.396 & -3.981 & 0.000 \\
\hline DAC*AUDT & 0.231 & 0.313 & 0.465 \\
\hline Adjusted R Square & & 0.372 & \\
F Statistic & & 9.977 & \\
Sig. F & & 0.000 &. \\
\hline Dependent Var: & CAR & & \\
\hline
\end{tabular}


UNISIA, Vol. XXXIV No. 77 Juli 2012

Berdasarkan tabel di atas, maka persamaan regresi adalah:

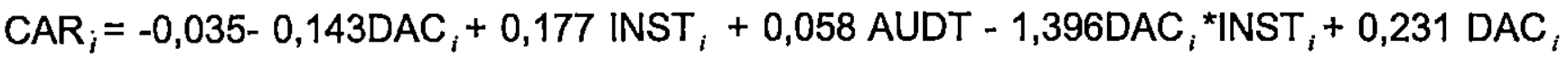
*AUDT,

Adapun pembahasan hasil pengujian hipotesis 2 dan 3 diuraikan sebagai berikut:

Kecanggihan investor, Manajemen laba dan Return Saham

Hipotesis alternatif 2 yang diajukan dalam penelitian ini adalah kecanggihan investor mempengaruhi hubungan antara manajemen laba sebelum IPO dengan return saham. ukuran perusahaan berpengaruh positif terhadap pengungkapan tanggung jawab sosial perusahaan.

Hasil uji interaksi antara variable DAC dan INST (DAC*INST) diperoleh koefisien regresi negatif sebesar $-1,396$ dan probabilitas sebesar 0,000 . Hasil ini berarti kecanggihan investor merupakan variabel yang memoderasi hubungan negatif antara manajemen laba dengan return saham. Semakin tinggi tingkat kecanggihan investor, maka hubungan antara manajemen laba dengan return saham akan semakin rendah (lemah) dan sebaliknya apabila semakin rendah tingkat kecanggihan investor, maka hubungan antara manajemen laba dengan return saham akan semakin kuat. Hal ini mengindikasikan bahwa dikarenakan sebagian besar investor yang melakukan perdagangan bukanlah investor yang canggih, maka kecenderungan manajemen dalam melakukan manajemen laba sebelum IPO masih terjadi, karena investor yang kurang canggih berarti tidak mampu menganalisis informasi secara benar. Dengan demikian hipotesis kedua yang menyatakan "kecerdasan investor mempengaruhi hubungan negatif antara manajemen laba dengan return saham" dapat didukung.

Hasil ini sesuai dengan hasil temuan Joni dan Jogiyanto(2009) yang menemukan bahwa hubungan manajemen laba dengan return saham yang mempertimbangkan faktor kecanggihan investor bernilai negatif. Hal ini menunjukkan bahwa manajemen laba yang tinggi menyebabkan nilai harga saham rendah ketika mempertimbangkan faktor kecanggihan investor. Hasil ini konsisten dengan penelitian Balsam et al. (2002) yang menyatakan bahwa manajemen laba berhubungan dengan return saham untuk investor yang canggih.

Hasil ini dapat dijelaskan bahwa investor yang canggih sebagai investor yang mampu mengumpulkan dan memproses informasi publik, sedangkan investor yang tidak canggih adalah investor yang hanya menggunakan informasi keuangan perspektif dan institusi serta tidak melakukan analisis laporan keuangan dengan baik. Umumnya kepemilikan institusi cocok dijadikan proksi kecerdasan investor adalah karena investor institusi memiliki informasi privat yang lebih banyak dan memiliki tim analis yang lebih canggih untuk menganalisis informasi daripada investor individu, selain itu investor institusi dianggap siap melakukan investasi pada sejumlah besar perusahaan. Semakin tinggi kecanggihan investor, maka tindakan manajemen laba yang dilakukan perusahaan sebelum IPO, akan cepat dideteksi sebagai tindakan manipulasi laba, sehingga informasi yang terkandung dalam laporan keuangan tidak mencerminkan kinerja keuangan perusahaan yang sesungguhnya, sehingga hal ini akan menurunkan return saham setelah perusahaan melakukan IPO. Sebaliknya investor yang tidak canggih, maka dalam keputusan investasinya hanya didasarkan pada informasi perspektif laporan keuangan saja, sehingga tidak mengetahui bahwa informasi dalam laporan keuangan telah dimanipulasi, sehingga mereka terlalu agresif dalam melakukan pembelian saham, dan akan meningkatkan return saham.

Kualitas Auditor, Manajemen Laba dan Return Saham

Hasil uji interaksi DAC dan AUDT (DAC*AUDT) diperoleh koefisien regresi positif sebesar 0,231 dan probabilitas sebesar465. Hasil ini berarti kualitas auditor bukan variabel 
yang moderasi hubungan antara manajemen laba dengan return saham. Dengan demikjan baik buruknya kualitas auditor tidak mempengaruhi hubungan antara manajemen laba dengan return saham Dengan demikian hipotesis ketiga yang menyatakan bahwa kualitas auditor mempengaruhi hubungan negatif antara manajemen laba dengan return saham,tidak didukung.

Hal ini mengindikasikan bahwa kualitas auditor tidak dapat membatasi besaran manajemen laba dalam mempengaruhi return saham, ini menggambarkan bahwa audit oleh KAP besar atau KAP yang memiliki pangsa pasar yang besar tidak menjadikan jaminan memberikan kualitas auditor lebih baik, sehingga tidak dapat menurunkan besaran manajemen laba secara signifikan.

Salah satu motivasi yang memicu munculnya tindakan manajemen laba adalah motivasi untuk memanfaatkan kegiatan Initial Public Offering (IPO) sebagai sebuah kondisi asimetri informasi dalam rangka mendapatkan harga saham perdana yang tinggi. Selain itu, perusahaan terdorong untuk melakukan manajemen laba adalah karena perusahaan berusaha untuk meningkatkan penjualan saham, menurunkan tingkat pajak, mendapatkan bonus. Sudah banyak penelitian-penelitian sebelumnya yang menemukan bahwa perusahaan cenderung melakukan manajemen laba sebelum melakukan IPO, sehingga penggunaan auditor yang berkualitas tidak mampu menghalangi tindakan manajer untuk melakukan manajemen laba, sehingga variabel ini tidak memoderasi hubüngan antara manajemen laba dengan return saham.

\section{Penutup}

Kesimpulan

Tujuan penelitian ini adalah untuk mendeteksi manajemen laba periode di sekitar IPO dan untuk menguji apakah kecanggihan investor dan kualitas auditor merupakan faktor yang mempengaruhi hubungan antara manajemen laba dengan return saham sebelum IPO. Berdasarkan hasil analisis dapat disimpulkan sebagai berikut:

1. Berdasarkan hasil uji beda one sample T-test menunjukkan bahwa manajemen cenderung melakukan tindakan manajemen laba pada periode 1 tahun sebelum IPO dengan cara meningkatkan laba (increasing income) dan pada periode terjadinya IPO dengan cara menurunkan laba (decreasing income).

2. Berdasarkan analisis regresi moderasi (MRA), kecanggihan investor berpengaruh negatif terhadap hubungan antara manajemen laba dengan return saham. Hal ini berarti semakin tinggi tingkat kecanggihan investor, maka tindakan manajemen laba akan mudah dideteksi secara awal dan merupakan informasi yang buruk yang akan menurunkan return saham setelah IPO. Sementara itu kualitas auditor tidak berpengaruh negatif terhadap hubungan antara Manajemen laba dengan return saham. Hal ini berarti, semakin baik/buruk kualitas auditor tidak mempengaruhi hubungan antara manajemen laba dengan return saham.

Keterbatasan Penelitian

Penelitian ini mempunyai beberapa keterbatasan sebagai berikut:

1. Jumlah sampel yang masih relatif kecil yang berjumlah 38 emiten, sehingga hasil penelitian ini kurang dapat digeneralisir.

2. Pengukuran return saham dalam penelitian ini hanya dalam jangka pendek saja yaitu 7 hari sesudah IPO, sehingga tidak diketahui apakah return saham cenderung menurun atau meningkat pasca IPO dalam jangka yang panjang. Hal ini tentunya tidak diketahui dampak manajemen laba terhadap kinerja saham dalam jangka panjang. 
3. Peneliti tidak menggunakan variabel kontrol dalam menguji pengaruh manajemen laba terhadap return saham, sehingga penurunan/peningkatan return saham pasca IPO benarbenar disebabkan oleh tindakan manajemen laba atau disebabkan oleh variabel lain yang tidak diteliti.

Saran untuk Penelitian Selanjutnya

Bagi penelitian selanjutnya diharapkan bisa menambah jumlah sampel dengan memperpanjang periode pengamatan. Selain itu peneliti selanjutnya dapat mengganti variabel return saham dalam jangka panjang, misalnya CAR 3 bulan, 1 tahun atau lainnya serta menambahkan variabel kontrol seperti ukuran perusahaan, leverage, jenis industri.

Implikasi Penelitian

Hasil penelitian ini mempunyai implikasi bagi investor agar sebelum melakukan investasi di pasar modal terutama pada perusahaan yang melakukan IPO hendaknya melakukan analisis lebih komprehensip tidak hanya pada prospectus dan laporan keuangan saja, tetapi juga dari sisi yang lain agar tidak terjebak oleh manipulasi isi laporan keuangan. Sebaliknya bagi perusahaan yang akan melakukan IPO, sebaiknya menghindari tindakan manajemen laba, karena investor yang canggih akan mampu mendeteksi tindakan manajemen laba yang dilakukan oleh perusahaan dan pada akhirnya akan berdampak pada penurunan harga saham setelah IPO.

\section{Referensi}

Aharony, Joseph, Chan-Jane Lin, dan Martin P. Loeb. 1993. Initial Public Offerings, Accounting Choices, and Earnings Management. Contemporary Accounting research, Vol 10, No. 1. Fall, p. 61-81.

Ardiati, Aloysia Yanti. 2005. "Pengaruh Manajemen Laba Terhadap Return Saham pada Perusahaan yang Diaudit oleh KAP Big 5 dan KAP Non Big 5". Jurnal Riset Indonesia, 8 (3) 235-249.

Balsam, Steven; Eli Bartov; dan Marquardt Carol. 2002. "Accruals Management, Investors Sophistication, and Equity Valuation: Evidence from 10-Q Filings". Journal of Accounting Research 40 (4).

Bartov, Eli; Suresh Radhakrishnan; dan Itzhak Krinsky. 2000. "Investor Sophistication and Patterns in Stock Returns after Earnings Announcements". The Accounting Review 75 (1): 43-63.

Dessy, Sandra dan Indra, Wijaya Kusuma. 2004. Reaksi Pasar terhadap Tindakan Perataan Laba dengan Kualitas Auditor dan Kepemilikan Manajerial sebagai Variabel Pemoderasi. Denpasar: SNA VII (tidak dipublikasikan), hal. 948-962.

Freidlan J. M. 1994.Accounting Choice of Issuers of Initial Public Offerings.Contemporary Accounting Research 11 (1): 1-31.

Gumanti, Tatang Ari. 2001. Earnings Management dalam Penawaran Saham Perdana di Bursa Efek Jakarta. Jurnal Riset indonesia, 4 (2) 165-183.

Hartono M., Jogiyanto. 2000. Teori Portofolio dan Analisis Investasi. BPFE, Yogyakarta, Edisi Kedua.

Hartono M., Jogiyanto. 2005. Pasar Efisien Secara Keputusan. Gramedia Pustaka Utama, Jakarta. 
Imam Sutanto, Intan. 2000. Indikasi Manajemen Laba (Earnings Management) Menjelang IPO oleh Perusahaan Yang Terdaftar di Bursa Efek Jakarta. Thesis S2 Akuntansi, UGM.

Jain, BharatA., dan Kini. 1994. The Post-Issue Operating Performance of Initial Public Operating Firms. Journal of Finance X:IX (5): 1699- 1726.

Joni dan Jogiyanto, H.M.2009.Hubungan Manajemen Laba sebelum IPO dan Return Saham dengan Kecerdasan Investor sebagai Variabel Pemoderasi. Palembang: SNA XII (tidak dipublikasikan).

Raharjono, Dominikus Agus Budi.2005. Hubungan Manajemen Laba Menjelang IPO dengan. Nilai Awal Perusahaan dan Retur Saham Setelah IPO.Thesis S2 Akuntansi, UGM.

Rajgopal, Shivaram; Mohan Venkatachalam; dan James Jiambalvo. 1999. Is Institutional Ownership Associated with Earnings Management and The Extent to which Stock Prices Reflect Future Earnings?. Working Paper.

Saiful. 2002. Analisis Hubungan Antara Manajemen Laba (Earnings Management) Dengan Kinerja Operasi dan Return Saham di Sekitar IPO .Thesis S2 Akuntansi, UGM.

Schipper, Katherine. 1989. Commentary on Earnings Management. Accounting Horizons, Vol 3, No.4, p. 91-102.

Teoh, Siew Hong; Ivo Welch; dan T. J. Wong.1998a. Earnings Management and Long-Run Market Performance of Initial Public Offerings.Journal of Finance LIII (6): 1935-1974.

Widjastuty, Erna. 2004. Pengaruh. Manajemen Laba Terhadap Return Saham. Thesis S2 Akuntansi, UGM. 